\title{
Professionalization of Human Resource Management in China: A Comparison Study to Law and Accountancy
}

\author{
Lingling Zhao \\ City University of Hong Kong, \\ Kowloon, Hong Kong, SRA
}

\begin{abstract}
This paper aims to explore the development of HR profession in China in a comparison perspective. The author assessed the degree of HR professionalization in China through Fanning's (2011) nine-characteristic model of HR profession. To better understand the extent of HR professionalization, the case of established professions-law and accountancy-are analyzed. Particularly, the professionality continuum in each profession is illustrated. In this paper, research questions concerning whether the HR profession is a semi or full profession, to what degree HR profession stands in the Chinese context, and how HR profession can become more professionalized are answered.
\end{abstract}

Keywords: Human Resource Management, Law, Accountancy, Professionalization

\section{INTRODUCTION}

With the increasingly important role of HR professionals, there has been a widespread and continual debate about whether or not HRM is making a bid for professional status and whether or not HRM is a full profession, compared with well-established professional careers (Sparrow and Chung, 2016; Storey, 2014). This paper focuses on HR professional status by detailing the application of Fanning's model to the nine characteristics of HR profession in China. By conducting documentary analysis of HRM in the UK and US, Fanning (2011) concludes that the HR profession can be described as a "semi-profession" since it scored highly on some indicators but lowly on others. However, few studies have been conducted regarding the process of HR professionalization and the extent of HR professionalization achieved in China. In order to understand where the HR profession stands in the Chinese society, the author analyzes the current situation of HR profession in China using Fanning's (2011) ninepoint model. The nine characteristics include the governing body, code of ethics, independence, legal status, certification and training, contribution to society, body of knowledge, research, and recognition.

\section{Degree of HR Professionalization in China The Governing Body in HR Profession}

The most influential official governing body exerting power on HRM in China is the Ministry of Human Resource and Social Security (MOHRSS), which is the main organization with the state authority to initiate policies and plans of people management nationwide. Regarding the state agencies in shaping HRM, the role of MOHRSS is to promote the integration of human and labor markets, enhance the establishment of a unified and standardized HR market, as well as reinforce the rational flow of HR and the efficient allocation of people. In reality, MOHRSS plays a vital role in the process of HR professionalization mainly through its policymaking process and authoritative influences on the supervision of the entire profession. For example, "HR service Profession Development Action Plan" was issued by MOHRSS in 2017. Subordinated to MOHRSS at the national level, there are Departments of Human Resources and Social Security 
in each province at the local level. Such departments are responsible for implementing specific policies issued by the central government.

Fanning's (2011) model explains the primary and secondary responsibilities of the HR governing body. According to the contents of documentary analysis and interviews, HR professional bodies in China have reached all the primary responsibilities requirements (see below, Table 1). Specifically, with regard to the "organize" function, HR professional bodies in China organize people with a particular interest. The organizing function is a continuous process and extends beyond the time of foundation. With regard to the "qualify" function, HR bodies in China have built up professional standards and qualifications to provide evidence of professional knowledge and experiences. Regarding the function of "research," HR professional bodies conduct relevant research in advancing HR professional status. Governing bodies in China also register competent professionals and promote and preserve a high standard of professional conduct.

However, when it comes to secondary responsibilities, HR governing bodies have not satisfied all of the items; for example, in terms of protecting their professionals, forming pressure groups, and providing welfare benefits, HR governing bodies are still at the early stage and in some cases, no such bodies have been formed yet. Consequently, the role of HR associations in the process of HR professionalization in China is still relatively weaker in such aspects as mentioned above, compared to professional bodies like CIPD and SHRM in Western countries, especially when it comes to the representative role of its members to negotiate with the government or lobby to the government. Concerning upgrading the status of HR profession, controlling entry, and socializing, such dimensions in the secondary responsibilities of Chinese HR professional associations have developed well and they continue to make efforts to reach higher levels. Table 1 shows both primary and secondary responsibilities of HR governing bodies and the levels they have reached so far in China, reflecting the maturity of HR profession in the Chinese context.

Table 1 Primary and Secondary Responsibilities of HR Governing Bodies

\begin{tabular}{|c|c|c|c|c|c|c|c|c|c|c|}
\hline \multicolumn{5}{|c|}{ Primary Responsibilities } & \multicolumn{6}{|c|}{ Secondary Responsibilities } \\
\hline Organize & Qualify & Research & Register & $\begin{array}{l}\text { Code of } \\
\text { Ethics }\end{array}$ & $\begin{array}{l}\text { Raise } \\
\text { Status }\end{array}$ & $\begin{array}{l}\text { Control } \\
\text { Entry }\end{array}$ & Protect & $\begin{array}{l}\text { Pressure } \\
\text { Group }\end{array}$ & Socialize & $\begin{array}{l}\text { Welfare } \\
\text { Benefits }\end{array}$ \\
\hline$\sqrt{ }$ & $\sqrt{ }$ & $\sqrt{ }$ & $\sqrt{ }$ & $\sqrt{ }$ & $\sqrt{ }$ & $\sqrt{ }$ & & & $\sqrt{ }$ & \\
\hline
\end{tabular}

\section{Code of Ethics in HR Profession}

The code of ethics in HR profession is the basic requirement to define HR practitioners' behavior and action at their workplace. According to the study of business ethics culture and HRM in China, there are some basic understandings of ethics for HR professionals in practice. First, HR practitioners should be familiar with and obey the Labor Law and other relevant laws, ensuring the legitimacy of the HR profession. Second, the sense of maintaining confidentiality should be very strong for HR practitioners; they are not allowed to deliver any confidential information to any third party without authority. Third, they are urged to ensure fairness and justice when processing HRM issues and also need to have a strong sense of integrity and honesty. Finally, HR practitioners should be dedicated to their work and enhance the professional reputations within the profession. In addition, different professional associations usually set their own code of ethics for their HR professional members to 
constrain their behavior. There are very specific requirements of code of ethics within HRA for their professional members, which exist and cover different aspects in the association. However, the effectiveness of such code of ethics in reality needs further examination. Currently, a huge problem facing China is that it lacks professional ethics, credit records, and a mechanism to differentiate unethical HR practitioners from ethical practitioners. Thus, the level of code of ethics is positioned in the region of semi-professional.

\section{Independence in HR Profession}

HR professionals should have independence in organizations by using their knowledge and skill to solve problems. However, the entire HR department in China is still not considered as a key part in an organization compared to other departments in both public and private sectors. Indeed HR professionals need to coordinate with other departments, such as the research and development department or finance department, for many issues. In reality, the decision needs to be agreed by the leaders in senior positions and the senior leaders in the organization rather than HR professionals always take the final decision. Further, HR professionals' decisions have to be consistent with the strategies and policies of the entire organization.

Moreover, the level of independence of HR profession is not high because of easy entry into the HR profession in China. Standards of entry into the HR profession are relatively lower than those in the established professions in China, partly because the history of HR profession is shorter and partly because the development of HRM began just after China opened up to the world market when Western management elements integrated into Chinese firms. Compared to law and accountancy professionals in China, HR professionals are not required to hold certification or similar licensing in their positions. Thus, the autonomy and independence of HR professionals in their workplace is still relatively low.

\section{Certification, Education, and Training in HR Profession}

Nowadays, the education, training, and certification evolve systematically in the Chinese HR community, and diverse programs have flourished in the market. Knowledge and education are highly valued by Chinese employees. After opening up to the world economy, many universities and colleges across China have opened HRM undergraduate programs, and several universities with highly ranked graduate or PhD programs intensively undertake cutting-edge research in labor and HRM-related issues, enhancing communication with world-class academic institutes ${ }^{1}$. Early in 1983, accompanied by the deepening of China's Reform and Opening-up policy, the Labor and Personnel Ministry of China established the first institute, the School of Labor and Human Resources, in Renmin University of China, intensively undertaking teaching and research tasks in the areas of the labor market, labor policies, laws and regulations, personnel management, and social security issues. Offering HR-related majors by Chinese universities indicates the significant progress in the development of HRM.

With the advancement of HRM in enterprises, a huge demand for professional talent has been created, and it maintains very important competitiveness of organizations. In practice, employee training has been treated as the best practice by most firms, and firms have been providing extensive training to improve their employees' knowledge, abilities, and skills. Providing adequate onboarding and continuous training are essential components of organizational HR strategy to address the talent shortage and retention challenges in China. Adequate training will not only help improve employees' competency, but also can significantly boost the morale and reduce turnover rates in organizations. From the rich information

${ }^{1}$ http://en.moe.gov.cn/Resources/Directories/ 
Chinese market provides, it can be concluded that the certification, education, and training aspects in HR profession are relatively developed.

\section{Legal Status in HR Profession}

Even though there are no direct laws that define what constitutes HR or what HR professionals are expected to do in their positions, relevant laws indirectly influencing the HR profession do exist in China. For instance, the Employment Promotion Law was issued in 2007, which aims to coordinate employment with economic development and promote the expansion of employment opportunities. This law emphasizes the responsibilities of the government for facilitating employment by creating a favorable market environment. In addition, the establishment of the New Labor Law in 2008 can be considered as one of the most significant events in China's labor legislation history, which highlights the legislative purpose of protecting the interests of laborers. Consequently, HR professionals are required to be familiar with the specific regulations and relevant systems of the New Labor Law, effectively reducing the employment risks in organizations. Another important law related to the HR profession is the Labor Dispute Mediation and Arbitration Law, which reduces the cost for labor dispute resolution and contributes to solving the problems in labor relations. The Social Insurance Law stipulates the key strategies of employees' insurance methods, which needs HR professionals to clearly understand the articles in the law. Overall, the implementation of important laws marks the labor legislation progress and the significance of the HR profession, indicating that the comprehensive construction of a legal environment for HRM development has begun.

While some Chinese small-medium enterprises (SMEs) are allowed to get away with minor infractions of the law, foreign-owned companies are usually held on a higher standard in HRM policies and institutions. In China, legislation should be an instrumental tool for modifying the HR practices and the requirements to constrain the HR profession need to be issued in the future. Even though there are relevant laws to protect both employees and employers, the legal status of HR professionals is still relatively lower than law and accountancy professionals because entry into the HR profession is not as strict compared to law and accounting professions in China.

\section{Contributions to Society in HR Profession}

HRM policies and practices in multinational enterprises and Chinese companies have made significant contributions to global leadership, global talent management, and labor relations in a wider HR community. According to the discussion of Storey (2014), HRM policies of HR professionals (e.g., the selection on the basis of specific criteria using sophisticated tests) have a significant influence on and contribute to the high commitment and quality of people in organizations. In doing so, HR professionals contribute to organizations by applying their professional knowledge and skills in the HRM domain. In China, effective HRM policies and strategies have been formulated to achieve low labor turnover and increase loyalty to the company (G. Wang et al., 2014). Furthermore, the functions of HRM contribute to creating and sustaining an ethical culture and climate at all levels in organizations in the Chinese context (Lin, 2011). In practice, Chinese companies, particularly large SOEs, contribute to creating favorable terms and conditions to attract talent externally, which forms a positive talent pool (Rowley \& Cooke, 2014). Thus, effective HR strategies can help to select and retain such talents to promote the performance of different organizations. HR professionals as the competitive advantages in fierce competition play a crucial role in enhancing the level of people management and making potential profits for companies in various industries. The application of innovative approaches in the HR profession is not only critical for Chinese economic development, but also for political, technological, socio-cultural and environmental developments in the entire society. 


\section{Body of Knowledge in HR Profession}

Besides possessing the basic knowledge and skills in the traditional HR modules, such as recruitment, selection, training, performance, and benefit management, Chinese HR professionals must be able to quickly learn the complexities of more strategic HR solutions rather than mastering the tactical implementation and execution of compensation and benefits strategies (Ngo et al., 2014). Strategic thinking should be HR professionals' new core competence that can add strategic value to the business by emphasizing results over processes (Cascio, 2015). HR professionals must be able to acquire new knowledge and skills for HR professionals at their workplace. As Akhtar and Renyong (2014) state, HR practitioners need to have the ability to mobilize the proper resources and a sense of timing and context at both local and global levels. Today, the Chinese government and business leaders increasingly value the contribution and importance of HR professionals. HR professionals must equip themselves with business knowledge and set priorities in the HR support they provide. Thus, HR professionals in China are urged to increasingly expand their knowledge base in order to adapt themselves to the changing market.

In practice, Chinese HR practitioners need to expand their knowledge base to gain a significant competitive edge in the global market. However, there is still lack of systematic HR professional knowledge and uniformity in standards set for the HR profession. HR practitioners must build a comprehensive structure of knowledge and have relevant knowledge in other fields (e.g., self-management ability, efficient execution ability, social skills, and innovation ability).

\section{Research in HR Profession}

In recent years, there has been a need for exploring additional studies because of the fast growth of demand in the HR market, although HRM issues in China have been examined from different perspectives. Major HRM research focuses on the development patterns and specific HRM modules, and study gaps exist in the area of HR professionalization, its ethics, and technology (Ngo et al., 2014; Sheldon et al., 2014; Warner, 2014). Leading research on Chinese HRM mainly stays close to the mainstream research, while maintaining independent thinking.

Many scholars discuss the general background of HRM and labor relations in China, which also analyzes the cultural values and political and economic systems shaping Chinese HRM policies and practices (Akhtar et al., 2014). It is important to balance theory-building and empirical contextualization in HRM research in China. In addition, researchers need to build logical conceptual frameworks to explain and predict the trends of HRM phenomena in China.

\section{Recognition in HR Profession}

Recognition from public and society is an essential element for the HR profession to become a full profession in China. For example, the recognition of HRM's strategic importance may make it more of a line management responsibility, particularly in areas involving the selection and compensation of HR managers (Martell and Carroll, 1995). By analyzing relevant professional theories in previous chapters, it can be concluded that a true profession should meet the basic criteria in the Chinese HR community. First, professionals should be able to solve problems that non-professionals cannot deal with. Second, the ability to solve problems is based on their mastery of professional knowledge and comprehensive understanding of the profession. Third, systematic training and education is necessary to expand the knowledge base. Finally, the profession should be accepted and recognized by the public as a true profession. Thus, recognition is one of the basic requirements for the HR profession to become a true profession. With respect to HR professionalization in China, there is still much room for improvement, 
including better recognition of its professional status along with further development of professionalization of HR.

Figure 1 HRM Professionality Continuum

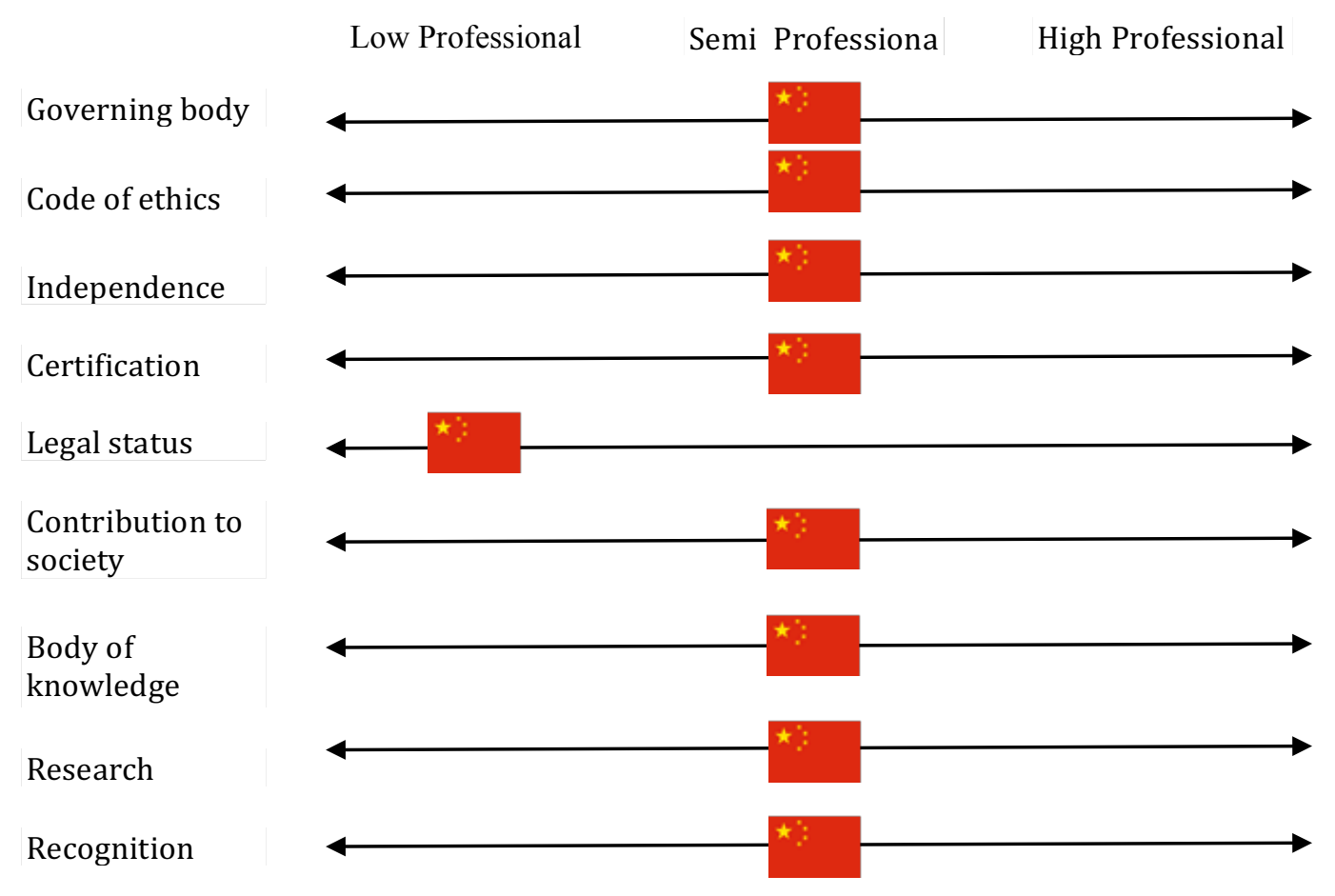

In sum, based on the analysis of the HR profession by adopting Fanning's nine-point model, Figure 1 profiles where the HR profession stands in the Chinese context. In general, the HR profession in China is still at a nascent stage because the scores in all the nine dimensions are relatively lower than established professions (see Figure 2 and Figure 3). As Balthazard (2014) notes, HR profession can be considered as a "semi-profession" because it has not yet been able to reach high professional status in many dimensions. Thus, it can be concluded that while the HR profession has made rapid progress after its establishment in China, it still has a long way to go to be considered as a true profession.

However, the more recent changes in the HR profession and its practice point to a transformation from a semi-profession to a true profession in the Chinese setting, for example, with more systematic education and training programs, detailed code of ethics of HR professionals, the expansion of HR expertise, and upgrading recognition of HR professional status. From this perspective, it is safe to argue that the HR profession in China is on its road to professionalization.

HR professionalization is necessary and desirable in China because it brings substantial benefits to the entire profession and organizations with which HR professionals are employed. Specifically, HR professionalization contributes to the improvement of the overall quality of HR professionals, by creating strict barriers to entry into the HR profession, which can change the chaotic state of HR inflow, as well as raising up the bottom line in the HR profession in China. Moreover, when the HR profession becomes more professionalized, it indicates that promotion has a clear standard to guide the career development of HR practitioners and training has a clear goal to provide a direction for the improvement of HR professionals' quality. In addition, HR professionalization encourages the establishment of an exit mechanism to eliminate HR practitioners with low quality. 
Furthermore, HR professionals both in Chinese private and public sectors are very important assets in their organizations. Accordingly, organizations benefit from HR professionalization through gaining better HR practitioners. In addition, HR professionalization is conducive to the reconstruction of social ethics because of the improvement of code of ethics in HR professionals. Moreover, HR professionals with higher professional status enable organizations to improve the performance. Specifically, recognized qualifications provide HR practitioners with the necessary knowledge and skills to perform professionally a wide range of jobs, including recruitment, training, and performance management and in the HRM field.

\section{Degree of Law Professionalization}

\section{The Governing Body in Law Profession}

The official professional association for lawyers is the All China Lawyers Association (ACLA). Founded in 1986, the ACLA carries out professional administration over lawyers by law, which is under the guidance of the Ministry of Justice and its bureau (Lo and Snape, 2005). There is a congress within ACLA called the National Lawyers Congress, which carries out important decisions for the law profession in China (Lo and Snape, 2005). The membership of ACLA is compulsory and all practicing lawyers in mainland of China are members of ACLA. Furthermore, the local bar associations are group members of ACLA. Thus, the law profession has a strict standard for enter into this profession in China. There are two levels of local bar associations: the provincial level and city level. Once the lawyers obtain the license in China, they will become members of ACLA automatically (the website of ACLA, 2016). The membership is permanent and law professionals are required to pass the annual check for registration. Every year the provincial bar association will collect the membership fee from practice lawyers and submit part of the membership fee to ACLA (McMorrow, 2015).

The duties of ACLA include ensuring that lawyers practice lawfully, setting standards and punishment rules, organizing legal training and education on professional ethics, rewarding and punishing lawyers and their firms, dealing with complaints against lawyers, and mediate disputes that arise in relation to lawyers' practices. Through its professional associations, lawyers have been given the opportunity to self-regulate, albeit with pervasive government influence ( $\mathrm{Wu}, 2013)$. As a result, the governing body plays a critical role in shaping and enhancing the status of the law profession through its professional functions in practice.

\section{Code of Ethics in Law Profession}

The profession gained significant importance when ACLA adopted its own ethical code in 1996. Its issue of the "Norms of Lawyers on Handling Criminal Cases" and "Regulations on the Punishment of the Members of the Lawyers' Association" has demonstrated that the association is in charge of the discipline of the profession (McMorrow, 2015). The code of ethics for law aims to promote and maintain the high standards of the profession (Flood, 2011). The original code of practice entitled "Lawyers' Ten Wanted and Ten Not Allowed" was issued in 1990, while the first formal document "The Norms on Professional Ethics and the Discipline of Practice of Lawyers" appeared in 1993. Related penal regulations issued later were the "Certain Regulations on the Rejection of Improper Conduct of Competition in the Legal Profession" and "Measures on the Punishment of Unlawful Conduct of Lawyers" to discipline lawyers who are found guilty of misconduct (McMorrow, 2015). There were also a set of code of ethics lawyers should follow in documents, which provides specific guidance for law professionals to obey (Lo and Snape, 2005).

The Lawyer's Law gives ACLA the responsibility to formulate professional regulations and rules of punishment, organize education and training in lawyers' professional ethics, and practice disciplines (McMorrow, 2015; Lo and Snape, 2005). Both the Ministry of Justice and 
ACLA have developed codes of ethics for law professionals (Michelson, 2006). In addition, the local authority is required to execute assessment of code of ethics for both individuals and organizations in the law profession (Wu et al., 2013). Even though there is still misconduct among lawyers and much space for improvement, ethical standards of the law profession as a whole are upgrading in China. Law firms are required to institute systems to monitor their lawyers for ethical violations and conflicts of interest, which will undoubtedly further raise the level of ethical standards (Wu, 2013; Flood, 2011; Alford, 2002). In this respect, the code of ethics of law profession is much more systematic and richer than that of the HR profession in China.

\section{Independence in Law Profession}

There has been apparent progress in the development of the law profession. Nevertheless, the profession is still characterized by a lack of independence from the state. In fact, lawyers' inferior status in the judicial process, heavy administrative interference in legal practice, and insufficient protection of lawyers' rights are obvious problems faced by the law profession in China (Lo and Snape, 2005). With the establishment of the Lawyer's Law of the PRC, the role of the law profession has experienced a dramatic change from workers of the state to legal practitioners who hold certificates to practice law and who provide legal services to the society. The establishment of independent law firms was encouraged, which further promotes the law professionalization and independence from the state (Liu, 2013; Clark, 2008; Alford, 2002).

The independence of the legal profession in China mainly relies on which specific areas lawyers are working on (Simon et al., 2016; Michelson, 2006; Gao, 2002). The Chinese judiciary is under direct control of the Ministry of Justice. Judges and prosecutors commonly appear more as government workers and extensions of party interests and less as independent actors. However, after the introduction of professional associations, the Ministry of Justice is no longer the only entity that has direct control over lawyers (Lo and Snape, 2005). Instead, the annual inspections of law firms are now conducted by the local lawyers' associations. Moreover, same local associations take most disciplinary actions, although some decisions are reserved for the Ministry of Justice (Michelson, 2006).

Chinese lawyers are not permitted to form their own lawyers' associations but must join those created by the state, and the national and local associations must follow the directives of the Ministry of Justice in general and its department on lawyers (Lo and Snape, 2005), which implies there is much room for improvement regarding the total independence of the law profession in China. Thus, increasing independence of the legal profession from the state is still a major theme in the evolution of the Chinese law profession (Feng et al., 2016; Gao, 2002).

\section{Certification, Education, and Training in Law Profession}

In 2001, the judicial examination system was established in China, which is the most significant symbol of the determination to professionalize law practitioners in the legal system (Lo and Snape, 2005). The certification of legal profession is issued only when applicants clear the National Judicial Examination, which is organized by the Ministry of Justice. In the current system, any individual who wants to enter into the law profession must clear the unified judicial examination, unless already qualified to practice before the establishment of the judicial examination system. Despite the low pass rate, increasing numbers of people are devoted themselves to taking the examination because it highly improves job prospects (Clark, 2008). 
In China, legal education is jointly governed by the Ministry of Education and the Ministry of Justice $(\mathrm{Wu}, 2013)$. While the Ministry of Education issues guidance on how to prepare higher education teaching materials, the Ministry of Justice prepares its own textbooks, and is apparently considered the most authoritative in China. The swift expansion of legal education is evident from increasing number of law professionals and Chinese lawyers' cohort is still growing stably (Simon et al., 2016; $\mathrm{Wu}, 2013$ ). In particular, ACLA has established a framework of three levels of training: ACLA conducts model training; local bar associations conduct most of the training courses; the law firms conduct the basic training (Michelson, 2006). According to the Law of Lawyers, every practicing lawyer must have at least 40 hours of professional training every year (Gao, 2002).

Moreover, an emphasis on practice rather than theory requires more attention being paid to legal analysis and skills, which will raise the base level of competence for young Chinese legal professionals. Another important step is to standardize the education that Chinese law students receive (Simon et al., 2016; Liu, 2013). Recently, in 2015, there are significant reforms in the law profession related to the qualification system by Chinese authorities, which requiring a unified training before entry to the profession (Chen, 2016; Simon et al., 2016).

\section{Legal Status in Law Profession}

Law professionals must hold the certification and pass the national judicial examination to practice in China (Wu, 2013). The "Provisional Regulations on the Lawyers of PRC" was adopted in 1980, which provided the legal foundation for professionalization, thus raising its legal status generally. Although there are provisions regarding what the qualifications of lawyers are and how to establish law companies as well as regulations of the law profession, such provisions were not clear (Alford, 2002). Consequently, the legislation was later revised as the "Lawyer's Law of the PRC" in 1997, which intended to frame the legal profession in the context of a market economy. The later version was more profession-centered, as it made the profession more independent of the state and granted it a higher degree of autonomy from the Ministry of Justice (Liu, 2013; Lo and Snape, 2005; Gao, 2002). The new Lawyers Law has made contributions to regulate the law profession and made great improvement by providing detailed provisions (Lo and Snape, 2005; Gao, 2002). Thus, the administration of the legal profession and legal practices were further improved with additional regulations in China (Alford, 2002).

However, the professional status of the law profession should be further improved $(\mathrm{Wu}, 2013)$. For instance, the lawyers' associations are not perceived as effective lobbying groups in China. As such, the lawyers' associations are more effective in their disciplinary role than as vehicles for furthering the interests of their registered members (Michelson, 2006).

\section{Contributions to Society in Law Profession}

With the help of professional lawyers and lawyers' associations, China's legal profession has made a very significant contribution to economic and social development. (Simon et al., 2016). Chinese lawyers are of great importance in the wider society, especially when the government has emphasized more on the rule of law in China (Cao, 2002). In practice, lawyers are important for both governments and businesses by analyzing potential risks and legal impact of various cases, which contributes to Chinese economy. In addition, in order to establish a more completed legal system in the context of China, professionals in law have played significant role in revising several laws needed for the system. In particular, in the National People's Congress, there is an increasing number of lawyers to become legislators (Shang, 2015). Moreover, lawyers provide professional legal counsel to numerous Chinese 
organizations to support their development and solve their problems. Thus, the growth of the legal profession as a whole continues to be important $(\mathrm{Wu}, 2013)$.

\section{Body of Knowledge in Law Profession}

The body of law knowledge covers a wide range of domain, such as the constitution, civil and commercial law, administrative law, economic law, social law, and criminal law. Lawyers are required to have a command of knowledge not only in the judicial area but also in relevant subjects like finance, policies, and administration. This reflects the contents law professionals are required to grasp. Chinese legal service sectors also provides necessary law knowledge for the society, which contributes to the base of the body of knowledge since China's entry into the World Trade Organization (WTO). With an increasingly growth of business transactions, mergers and acquisitions, as well as copyright law, Chinese lawyers need to keep abreast of law knowledge in such areas and further develop their expertise in practice. Moreover, lawyers should have knowledge of the correct attitude in their workplace (Simon et al., 2016).

\section{Research in Law Profession}

Research on legal profession is primarily conducted by the Department of Law in Chinese universities. In general, scholars of law devote themselves to teaching and research. The most famous "Five Institutes" include the China University of Political Science and Law, Southwest University of Political Science and Law, East China University of Politics and Law, Zhongnan University of Economics and Law, and Northwest Institute of Political Science and Law, which provide both full-time degrees of law major and on-job training programs in law in order to train future lawyers and judges. Furthermore, "Four Departments," namely, Renmin University of China School of Law, Peking University Law School, Wuhan University Law School, and Jilin University School of Law, are famous and primarily responsible for research in law. Moreover, professional institutions and associations, such as the Profession Development Research Section in ACLA, provide relevant professional research (McMorrow, 2015). Research is increasingly being conducted by different institutions in China with a wide range of topics in various law areas.

\section{Recognition in Law Profession}

The significance of law professionals and their public recognition has been highlighted by increasing numbers of Chinese leaders. Chinese legal scholars and relevant institutions have made significant efforts to promote law professionalization in China (Xiandan, 2003). The status of legal professionals has also been promoted by many leaders who have often spoken of the necessity of enhancing the country's legal system. For example, the current President Xi Jinping claimed many times in his public speech that "No organization or individual has the privilege to overstep the Constitution and the Law." Consequently, legal professionals are vital for the new leadership in China and they comprise an important elite group in the society. To a great extent, for the party leadership, there is a tendency of including more people who have a law degree. As a result, the recognition of the law profession has been enhanced in many aspects in the entire society (Simon et al., 2016).

It is commonly believed that Chinese lawyers represent an increasingly important element in business, government, and society. Chinese lawyers are not merely representatives of a rising group of professionals but constitute the very core of the world's largest and oldest civilization entering into the modern era. Overall, the recognition of lawyers in the Chinese society is higher than other professions because of the professional level they have attained. Following Fanning's model (2011), Figure 2 summarizes the degree of professionalization associated with the law profession in China. 
Figure 2 Law Professionality Continuum

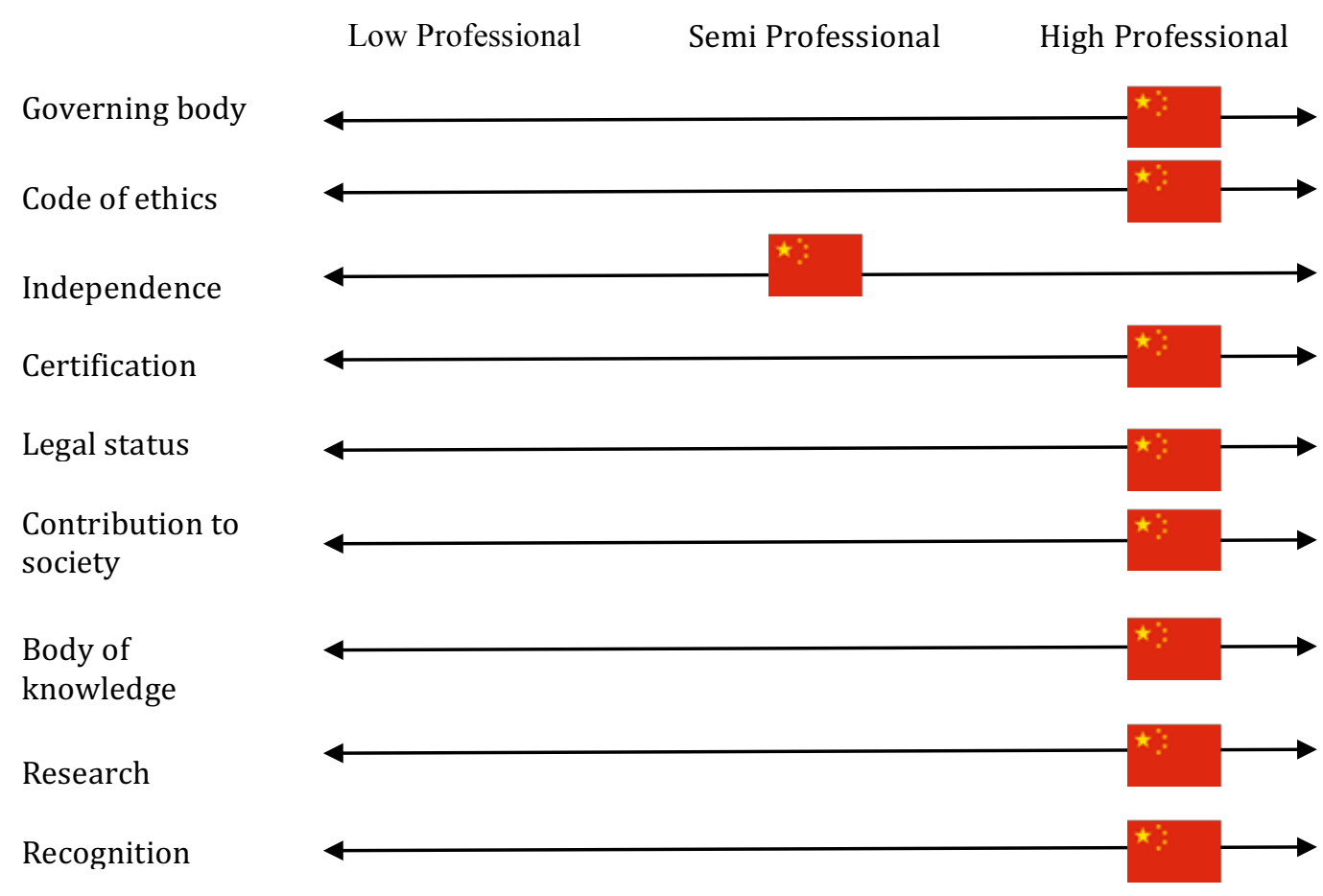

Figure 2 shows that the law profession ranks highly in many dimensions and it can be duly categorized as an established profession. However, the profession also has its own problems and pressures in the process of extensive professionalization (Flood, 2011; Lo and Snape, 2005). For example, from the theoretical perspective, even though the law profession has a systematic code of ethics, it is very difficult to apply the code in reality because of Guanxi in Chinese culture. Furthermore, the independence of the legal profession is relatively low when considered in the context of its political environment (Liebman, 2014; He, 2005).

\section{Degree of Accountancy Professionalization}

\section{The Governing Body in Accountancy Profession}

The most important governing body of China's accountancy profession is the Chinese Institute of Certified Public Accountants (CICPA). The accountancy profession begun to emerge in China in 1989 at the time of CICPA was set up to represent the profession (Gillis, 2014; Wei and Eddie, 1996). The CICPA was in charged by the Ministry of Finance in China and stipulated by the Charter of the Chinese Institute of Certified Public Accountants (CPAs) (Gao, 1992). Concerning the functions and roles, CICPA has provided professional service for its members and endeavors to establish professional status of the profession. According to the website of the CICPA (2016), there are different service systems provided by the professional body; such as the high entry standards system, the lifelong learning system, the code of ethics system and the international cooperation system. Such professional systems are built for better service, supervision, regulation, and coordination in accountancy profession.

Regarding international cooperation, the CICPA was the member of the Confederation of Asian and Pacific Accountants (CAPA) and the International Federation of Accountants (IFAC) since 1990s. In addition, the CICPA participate actively in the international conferences, which exerts significant influence on the international accountancy standards' development and revision. CICPA has contributed to advance the profession status and regularly promotes cutting-edge research around the world, which helps to keep pace of the global trends and achievements 
(the CICPA website, 2016). Moreover, CICPA assist the state with supervising CPAs and accounting companies, in accordance with the economic agenda of the state (Yee, 2012). From the above, it can be seen that the CICPA as the governing body of accountancy has gradually evolved to become a very mature and national professional association in China.

\section{Code of Ethics in Accountancy Profession}

With respect to codes of ethics, the professional integrity is important for the accountancy profession, which runs through all the fields and the whole process of accounting work. Professionals who abide by the accounting ethics help the organization to provide an objective and fair accounting information as well as ensure organizations' economic activity, compliance, supervision over the authenticity, and legitimacy. Specifically, in 2002, CICPA first released the tentative version of profession codes of ethics. Thereafter, in 2009, the governing body issued “The code of Ethics for Chinese CPAs” (“中國註冊會計師職業道德守則”in Chinese) and “Code of Ethics for Non-Practicing Members of the CICPA” (“中國註冊會計師協會非執業會員職業道 德守則” in Chinese). Such codes of ethics systematically and comprehensively elaborated ethical standards of CPAs and non-practicing members, which made great progresses in strengthening the ethics education and improving the practice of CPAs as well as deepening integrity building for the accountancy profession. As the essential property and the core value, the integrity is the cornerstone of the existence and development and the fundamental guarantee for the scientific development of the accountancy profession (Ji, 2000).

\section{Independence in Accountancy Profession}

According to the Charters of the CICPA, CPAs are required to perform impartially, objectively, and be responsible for the professional reports delivered. It is important to understand that the accountancy profession was largely influenced by the authoritative in China (Yihua, 2012). CPAs in China did not proactively organize themselves to become a self-regulated body at the beginning. The steps for the development of the accountancy profession were directly organized by the state. In a wide range of organizations, the accountants have a good command of professional knowledge and skills, which implies that professionals are able to apply their competences and abilities into the workplace. However, the accountancy profession in China is still not independent because of the influence from leaders in the organizations and the outside political and economic environment. In particular, compared to the local market, the foreign forces strongly influence the development of the accountancy profession in China (Lin and Chan, 2000). Nevertheless, the state still supervise and influence the foreign impact in Chinese market. In order to enhance the independence and performance of the accountancy profession, it is highly necessary to change the perception of accountancy to a valued and essential composition in the corporate governance and social development (Berger et al., 2013).

\section{Certification, Education, and Training in Accountancy Profession}

In China, the CPA examination is one of the most difficult examinations in the accountancy profession. The basic salary of the certification holders is considerably high and increases stably over time. Thus, the CPAs who passed the examination can be considered as the scarce talents and receive a higher recognition in the professional accountancy domain. Accountancy is one of the most popular subjects in universities among Chinese students not only because it processes very useful knowledge base for the future job but also because it has competitive advantages for better returns at the workplace (Habib, 2015; Shuping, 2003). In order to promote the competitiveness of Chinese accounting firms, CICPA has launched a wide range of strategies and a clear agenda of professional training programs, which included both CPAs and non-practicing members. There is an increasing number of CPA majors in Chinese universities and colleges, which provide specific guidance and an increase of interest in the accountancy profession. Additionally, CICPA endeavors to build a platform between students in CPA majors 
and the accountancy profession, which highlights the importance of the education and training in the profession (Tang, 2000; Wei and Eddie, 1996).

\section{Legal Status in Accountancy Profession}

Accountancy is a more established profession than the HR profession mainly because its legislative level is authorized by the state (Chan et al., 1996). Accountancy professionals must have certain knowledge and skills as well as hold the necessary certification to work in relevant positions. The certification is much more stringent in this profession, compared to the HR profession, in which certification is not a requirement in the professional jobs. After economic reform and opening up policies, the Ministry of Finance restored the CPA system in the late 1980s. Afterwards, in 1986 Promulgation of the CPA Regulations was issued by the Central government (Ezaki and Sun, 1999). Thereafter, another important milestone of accountancy profession was the release of the Law of PRC on CPAs in 1993, which indicates that the special legislation and the legal status of the accountancy profession have established in China. The Law has a comprehensive and representative guidance in the accountancy profession, which defines the responsibilities of CPAs and the accounting companies (Zhang et al., 2014).

\section{Contributions to Society in Accountancy Profession}

Since the establishment of the accountancy profession, the occupation has generated many positive contributions in the society and has brought considerable profits to the Chinese market (Baker et al., 2010). The accountancy profession has provided the valuable and necessary information for companies' investment, which guarantees stability of the capital market in China (Gillis, 2014). Moreover, the profession provides solutions for business success and the adjustment of business strategy as well as supports the implementation of important policies at the national level. Currently, China's efforts and achievements in the accountancy profession are highly praised by the international organizations, contributing to the international accounting standards. Thus, the accountancy profession has the ability to drive national and regional economic development.

\section{Body of Knowledge in Accountancy Profession}

The Chinese government is working closely with local accounting professions to make necessary changes in the body of knowledge. There are six major domain of the body of knowledge for CPAs to command: auditing, the Law of Tax, the Law of Economy, the financial cost management, as well as the corporate strategy and risk management (The Website of the CICPA, 2017). The body of knowledge in the accountancy profession includes professional standards and rules can be adopted in practice. According to Law of CPAs, the Ministry of Finance is responsible for final approval and release such standards (Yihua, 2012). In 2009, the reports published by the World Bank states that "China's strategy of convergence of international standards can be one for other countries to follow", which means the standards of the accountancy profession in China reached the international level (Hail et al., 2010, p136).

\section{Research in Accountancy Profession}

Various accountancy professional-related bodies are committed to rich research investment in China (Yihua, 2012; Lin and Chan, 2000). For example, the World Bank and the WTO initiate numerous projects and research related to the development of the accountancy profession in China. Based on interviews conducted in the UK, Hong Kong and Mainland China, Macve's (2015) research concludes that the role of Chinese accountancy may prove to more significant in the future global development of the accounting system. Thus, the research in accountancy profession exerts significant influence on promoting the status of the profession. There is also sufficient research concerning the practices of the accountancy profession in the four Cross- 
Straits area of China (Rowley and Cooke, 2014; Huang et al., 2013). The aims of such research are to enhance the economic cooperation in different areas through deepening exchanges and cooperation of the local profession and with international standards at the global level (Macve, 2015).

\section{Recognition in Accountancy Profession}

In general, Chinese accountancy profession is a widely recognized profession with high professional status since its establishment. Accounting reforms allow Chinese individuals and companies to do business more easily with other industrial countries. However, the role of accounting departments in some organizations is still in low competency (Sangster, 2015; Huang et al., 2013). Compared to the mature markets in Western countries the accountancy profession in China is still on the road to achieve a higher status. Today, China's accountancy profession is well headed down the path of achieving convergence with international professional standards. Indeed, in line with economic development, China is exerting tremendous influence on the global stage, indicating the increasing recognition of the accountancy profession.

Figure 3 Accountancy Professionality Continuum

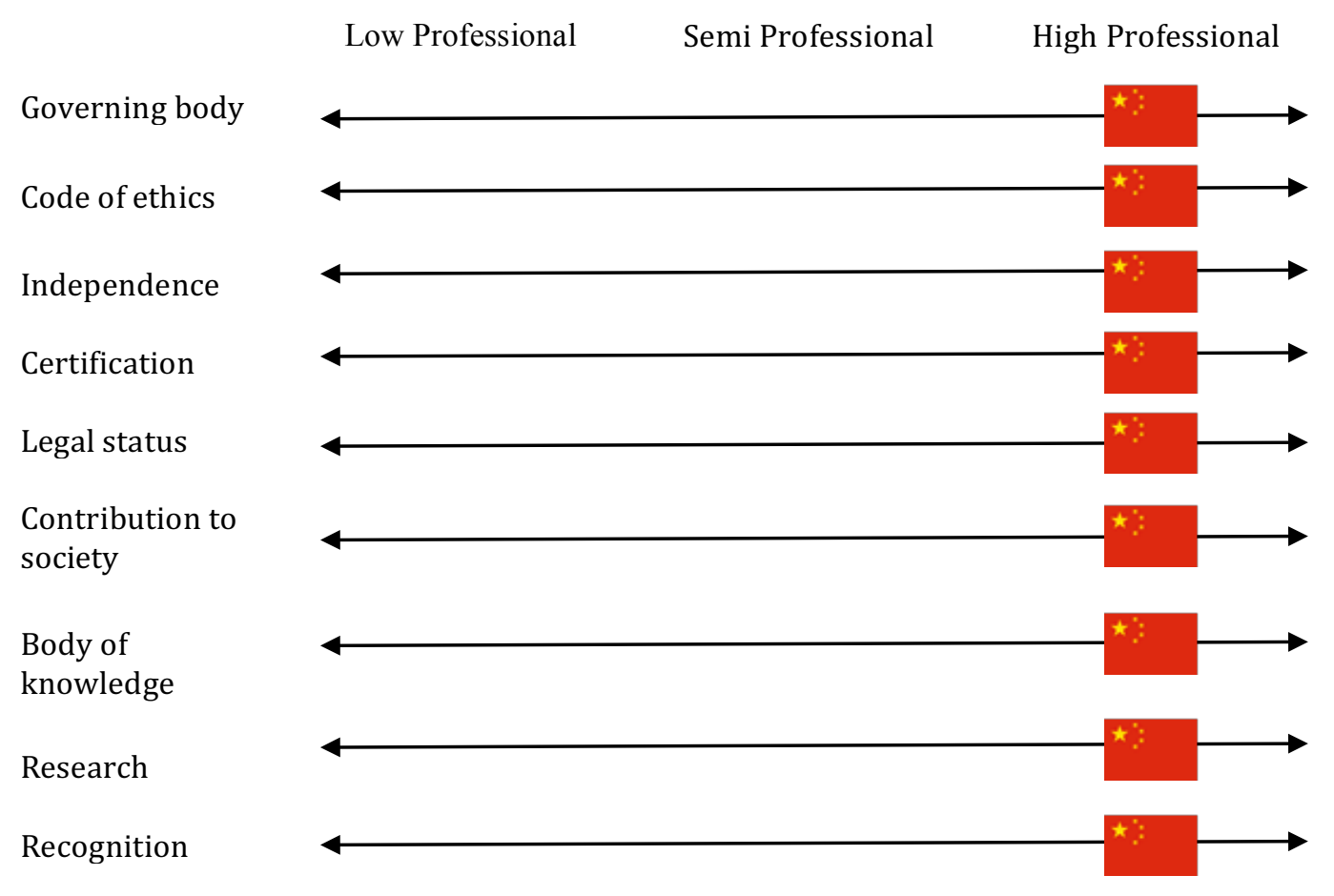

Based on the discussion above, Figure 3 shows a basic assessment of China's accountancy profession in the nine characteristics. From the analysis of each dimension, it is demonstrated that China's accountancy profession is an emerging and established profession as it scores highly in most traits that constitute a profession. In practice, the governing body of the Chinese accountancy profession has reached the international level in many aspects with respect to both size of members and professional services (Suddaby and Muzio, 2015; Wagner et al., 2014). Moreover, the code of ethics has gradually evolved to the extent that there is exact guidance on best practice and what kind of behavior is forbidden in the regulations (Zhang, 2015). In the dimension of independence, the accountancy profession still needs to improve because the professionals' decisions are partially influenced by outsider control. With regard to certification, education, and training, the CICPA delivers professional services and makes efforts to enhance the professional level of CAPs. Regarding legal status, the accountancy 
profession is the first profession with the protection of legislation and CPAs are legalized in China (Yihua, 2012). In terms of contribution to society, accountancy exerts influence on various areas (Friedman and Woodhead, 2007). There is rich information related to the body of knowledge, which is in line with international standards. Compared to the prolonged history of research in accountancy profession in Western countries, research in China is still limited to certain topics and the domain lacks comparison studies. Even though accountancy professionals have improved their status, the recognition of this profession needs more time to be accepted as a profession with higher status in the Chinese society (Macve, 2015). In summary, the Chinese accountancy profession can be seen as a true and well-established profession as most of Fanning's (2011) characteristics have attained a full professional standing.

\section{CONCLUSION}

This paper examines law, an established profession, and accountancy, an emerging profession, since these two professions provide useful insights from which to consider the case of HR profession. For instance, HR budgeting typically entails an accountancy dimension, while industrial relations and employment laws are legalistic in identity. The author analyzes law and accountancy professions both because of their high degree of recognition and status in China and because they also embody traits apparent in HRM (e.g., regulations and budgeting) (Evetts, 2015). Theoretically speaking, the law profession is categorized as a well-established profession in China, while the accountancy profession categorized as an emerging established profession and HRM is considered as a corporate profession (Zhao, 2017). In particular, the traditional professionalization process emphasizes monopoly, control, and self-regulation.

However, it is unattractive and unattainable for new expert professions in the modern society, such as HR; HR professionalization focuses more on entrepreneurial and managerial forms of organizations (Brock, 2016; Dent et al., 2016; Abbott, 2014). A key feature of such corporate professions is the increasing recognition of the importance of employing organizations as sites of professional formation and regulation. This feature has created a series of new policies and practices, such as corporate membership schemes and training courses, which are designed to engage with corporate interests (Suddaby and Viale, 2011). In reality, HRM as one of the corporate professions relies more on its serving organizations and develops its membership and training systems in professional associations. The assessment of the degrees of law and accountancy professionalization enables us have a better understanding of the status and position of HR profession in China, by a comparative analysis of the main characteristics. As the specific discussion above, Table 2 shows the degrees of HR, law and accountancy professional status in China.

Table 2 Comparison to Professionalization of HR, Law and Accountancy in China

\begin{tabular}{llll}
\hline & HRM & Law & Accountancy \\
\hline Governing Body & Semi & High & High \\
$\begin{array}{l}\text { Codes of Ethics } \\
\text { Independence }\end{array}$ & Semi & High & High \\
$\begin{array}{l}\text { Certification, Education, } \\
\text { Training }\end{array}$ & Semi & Semi & High \\
Legal Status & & High & High \\
$\begin{array}{l}\text { Contribution to Society } \\
\text { Body of Knowledge }\end{array}$ & Low & High & High \\
$\begin{array}{l}\text { Research } \\
\text { Recognition }\end{array}$ & Semi & High & High \\
\hline
\end{tabular}


As shown in Table 2, the degree of HR professionalization in China compared to established professions such as law and accountancy each profession's professionality continuum is different in all the nine indicators. The nine dimensions of both the law and accountancy professions have a high score, indicating an approximately high professional status. However, in the HR profession, most of the characteristics of professionalization are located in the semiprofessional status, and even for some indicators, such as independence, the HR profession stands in the low professional status. Indeed, the three professions are at different levels of professionalization. Law and accountancy can be considered as more mature professions than the HR profession. An assessment using the dimensions in Fanning's (2011) model indicates that the HR profession in China is still on the road to professionalization. In other words, the professionalization of HR is still at the nascent stage in China compared to more established professions, which indicates its semi-professional characteristics, even though the HR profession is making endeavors to achieve full professionalization.

Evidence suggests that the HR profession is a semi-profession when compared to law and accountancy professions in China. The governing body of the law profession, ACLA, was established in 1986 and that of the accountancy profession, CICPA, was founded in 1988. On the other hand, HRA was established much later in 1996, and MOHRSS was founded in 2008. From the timeline, HR profession is a new profession that has a relatively short history of development. The influences of the governing bodies are stronger in law and accountancy, for example, the membership of ACLA is compulsory and the certification of CPA launched by CICPA is compulsory to hold a position in accountancy. However, in the HR profession, professional certification is not compulsory, and even in some jobs, the relevant education is not a requirement. While accounting professional standards have become a global common system, most HR staff in China are unaware of the People Capability Maturity Model as a basic understanding of the global HR profession, indicating that the system of HRM professional standards is not yet mature. The code of ethics in law and accountancy are stringent and the governing bodies have the right to disqualify the professional members if they violate the regulations in their positions. However, in the HR profession, the code of ethics is just a requirement for members' behavior and conduct, which has little binding force. Furthermore, the independence in the HR profession is lower compared to law and accountancy professions because HR professionals in organizations always play a supportive role in decision-making processes. Thus, the recognition of the entire HR profession is much lower than that of law and accountancy, even though HR professionals make significant contributions to the Chinese society and play an increasing important role in adding competitive advantages to different organizations.

In sum, according to the assessment of HR professionalization in this paper, HRM can be viewed as a new emerging profession because there is a defined body of knowledge, certification is available, a code of ethics exists, and it has the support of a professional association. The reasons for considering HRM as a profession become even stronger with a well-established certification system and educational guidelines embraced by growing numbers of professionals, students, and academicians.

\section{Reference}

Abbott, A. (2014). The System of Professions: An Essay of the Division of Expert Labor. University of Chicago Press.

Alford, W. P. (2002). Of Lawyers Lost and Found: Searching for legal professionalism in the People's Republic of China.

Akhtar, S. H., \& Renyong, H. (2014). Assessment of Human Resource Management Environment in China: Past, Present and Future. Assessment, 6(36). 
Balthazard, C. (2014). The Professionalization of Human Resources. Kingston, ON: Queen's University IRC.

Berger, A., Busse, M., Nunnenkamp, P., \& Roy, M. (2013). Do trade and investment agreements lead to more FDI? Accounting for key provisions inside the black box. International Economics and Economic Policy, 10(2): 247-275.

Brewster, C., Chung, C., \& Sparrow, P. (2016). Globalizing Human Resource Management. Routledge.

Brock, D. M. (2016). Professionals and Their Workplaces in Emerging Markets-A Research Agenda. International Journal of Emerging Markets, 11(3): 460-472.

Cascio, W. F. (2015). Strategic HRM: Too important for an insular approach. Human Resource Management, 54(3): 423-426.

Chan, J. L., Jones, R. H., \& Lüder, K. G. (1996). Modeling governmental accounting innovations. Research in Governmental and Nonprofit Accounting, 9, 1-19.

Chen, J. (2007). The Transformation of Chinese Law-From Formal to Substantial. Hong Kong LJ, 37, 689.

Dent, M., Bourgeault, I. L., Denis, J. L., \& Kuhlmann, E. (2016). The Routledge Companion to the Professions and Professionalism. Routledge.

Evetts, J. (2015). Professionalism, Enterprise and the Market: contradictory or complementary? The Futures of Legal Education and the Legal Profession, 23-36.

Ezaki, M., \& Sun, L. (1999). Growth accounting in China for national, regional, and provincial economies: 19811995. Asian Economic Journal, 13(1): 39-71.

Fanning, B. (2011). Human Resource Management: The road to professionalization in the UK and USA. Unpublished Master's thesis, Kingston University, London.

Flood, J. (2011). The Re-Organization and Re-Professionalization of Large Law Firms in the 21st Century: From Patriarchy to Democracy. J. Legal Prof., 36, 415.

Friedman, A., \& Woodhead, S. (2007). Approaches to CPD Measurement Research Project. Accounting Education, 16(4): 431-432.

Gao, L. (2002). What Makes a Lawyer in China-The Chinese Legal Education System after China's Entry into the WTO.Willamette J. Int'l L. \& Dis. Res., 10, 197.

Gillis, P. (2014). The Big Four and the development of the accounting profession in China. Emerald Group Publishing.

Habib, A. (2015). The new Chinese accounting standards and audit report lag. International Journal of Auditing, 19(1): 1-14.

Hail, L., Leuz, C., \& Wysocki, P. (2010). Global Accounting Convergence and the Potential Adoption of IFRS by the US (Part II): Political Factors and Future Scenarios for US Accounting Standards. Accounting Horizons, 24(4): 567588.

Higgins, P., Roper, I., \& Gamwell, S. (2016). 14. HRM as an emerging new managerial profession. Perspectives on Contemporary Professional Work: Challenges and Experiences, 286.

Ji, X. D. (2000). Evaluation of research on Chinese accounting issues. Managerial Finance, 26(5): 41-62.

Liebman, B. L. (2014). Legal Reform: China's Law-stability Paradox. Daedalus, 143(2): 96-109.

Lin, L. H. (2011). Cultural and Organizational Antecedents of Guanxi: The Chinese Cases. Journal of Business Ethics, 99(3): 441-451.

Lin, K. Z., \& Chan, K. H. (2000). Auditing standards in China-A comparative analysis with relevant international standards and guidelines. The International Journal of Accounting, 35(4), 559-577.

Liu, S. (2013). The Legal Profession as a Social Process: A Theory on Lawyers and Globalization. Law \& Social Inquiry, 38(3): 670-693.

Lo, C. W. H., \& Snape, E. (2005). Lawyers in the People's Republic of China: A study of commitment and professionalization. The American Journal of Comparative Law, 53(2): 433-455.

Macve, R. (2015, July). The Future Structure of the Global Accounting and Auditing Profession: Western and Chinese Perspectives. In 27th Annual Meeting. Sase.

Martell, K., \& Carroll, S. J. (1995). How strategic is HRM? Human Resource Management, 34(2):253-267. 
McMorrow, J. A. (2010). Professional Responsibility in an Uncertain Profession: Legal Ethics in China. Akron L. Rev., 43, 1081.

Michelson, E. (2006). The practice of law as an obstacle to justice: Chinese lawyers at work. Law \& Society Review, 40(1): 1-38.

Ngo, H. Y., Jiang, C. Y., \& Loi, R. (2014). Linking HRM competency to firm performance: an empirical investigation of Chinese firms. Personnel Review, 43(6): 898-914.

Rowley, C., \& Cooke, F. L. (Eds.). (2014). The changing face of management in China. Routledge.

Sangster, A. (2015). The genesis of double entry bookkeeping. The Accounting Review, 91(1): 299-315.

Sheldon, P., Sun, J. J. M., \& Sanders, K. (2014). Special issue on HRM in China: differences within the country: International Journal of Human Resource Management.

Simon, T. W., Feng, C., \& Nelson, L. P. (2016). China's Changing Legal System: Lawyers \& Judges on Civil \& Criminal Law. Springer.

Storey, J. (2014). New Perspectives on Human Resource Management (Routledge Revivals). Routledge.

Suddaby, R., \& Muzio, D. (2015). Theoretical perspectives on the professions. The Oxford Handbook of Professional Service Firms, 25-47.

Suddaby, R., \& Viale, T. (2011). Professionals and Field-level Change: Institutional Work and the Professional Project. Current Sociology, 59(4): 423-442.

Tang, Y. (2000). Bumpy road leading to internationalization: A review of accounting development in China. Accounting Horizons, 14(1): 93-102.

Ulrich, D., Younger, J., Brockbank, W., \& Ulrich, M. D. (2013). The state of the HR profession. Human Resource Management, 52(3): 457-471.

Wagner, S., Hoisl, K., \& Thoma, G. (2014). Overcoming Localization of Knowledge-the Role of Professional Service Firms. Strategic Management Journal, 35(11): 1671-1688.

Warner, M. (Ed.). (2014). Confucian HRM in greater China: Theory and practice. Routledge.

Wei, L., \& Eddie, I. (1996). Accounting Reform in the People's Republic of China: Background and Current Developments. Accounting Research Study, (15).

Wu, R. (2013). China: Strengthening Lawyers' Discipline-A Great Leap Forward. Legal Ethics, 16(2): 377-379.

Xiandan, H. (2003). The Legal Profession and the Cultivation of Talented Legal Persons [J]. Cass Journal of Law, 4, 006.

Yee, H. (2012). Analyzing the State-accounting Profession Dynamic: Some Insights from the Professionalization Experience in China. Accounting, Organizations and Society, 37(6), 426-444.

Zhang, G., Boyce, G., \& Ahmed, K. (2014). Institutional changes in university accounting education in postrevolutionary China: From political orientation to internationalization. Critical Perspectives on Accounting, 25(8): 819-843.

Zhang, M. (2012). The development of Human Resource Management in China: An overview.

Zhao, L. (2017). Human Resource Management as a Corporate Profession. Journal of Business Management, 3(6): 17-28. International Journal of Research \& Development Organization.

Zhao, L., \& Higgins, P. (2017). Professionalization of Human Resource Management in China: the Role of Associations. Journal of Advanced Management Science, 5(3): 219-225.

Zhao, L., \& Higgins, P. (2012). Professionalization of Human Resource Management in China: The Role of Associations. World, 3. 